\title{
Nilai-Nilai Sejarah Kemaliq Lingsar dan Perannya Bagi Kehidupan Masyarakat Desa Lingsar Lombok Barat
}

\author{
Zidni $^{1,}$ Suhupawati ${ }^{2}$, B. Fitri Rahmawati ${ }^{3}$, Muhammad Shulhan Hadi ${ }^{4}$ \\ 1,2,3,4 Universitas Hamzanwadi \\ zidni@gmail.com \\ fitri.rahmawati@gmail.com \\ suhupawati@gmail.com \\ muhammadshulhan.hadi@hamzanwadi.ac.id
}

\begin{abstract}
Abstrak
Kemaliq Lingsar merupakan tempat yang dianggap suci oleh masyarakat sasak baik yang beragama Islam maupun Hindu. Kemaliq Lingsar merupakan bukti peninggalan sejarah penyebaran agama islam di daerah Lingsar yang berada di komplek Pure Lingsar. Tujuan penelitian ini adalah untuk menjelaskan tentang sejarah Kemaliq Lingsar, nilai-nilai yang terdapat pada Kemaliq Lingsar, dan peranan Kemaliq Lingsar bagi kehidupan masyarakat di Desa Lingsar Kecamatan Lingsar Kabupaten Lombok Barat. Metode penelitian ini menggunakan metode kualitatif. Data diperoleh melalui teknik observasi, wawancara dan dokumentasi. Teknik analisis data menggunakan reduksi data, analisis data, dan verifikasi data atau penarikan kesimpulan. Hasil penelitian menunjukkan bahwa Kemaliq Lingsar merupakan bangunan bersejarah yang berada di dalam komplek pure lingsar. Kemaliq dibangun pada abad ke-15 M oleh Datuk Milir. Kemaliq ini kemudian dipugar oleh Anak Agung Karang Asem Bali tahun 1714 karena berada satu komplek dengan Pura Gaduh yang dibangun sebagai tempat beribadahnya umat Hhindu. Kemaliq lingsar memiliki nilai sosial, nilai agama dan nilai budaya bagi kehidupan masyarakat Lingsar. Selain itu Kemaliq Lingsar memiliki peran dalam agama, sosial, dan ekonomi dalam kehidupan masyarakat Lingsar.
\end{abstract}

Kata Kunci: Nilai Sejarah, Kemaliq Lingsar, Masyarakat

\begin{abstract}
Kemaliq Lingsar is a place that is considered sacred by the Sasak community, both Muslims and Hindus. Kemaliq Lingsar is evidence of the historical legacy of the spread of islam in the Lingsar area which is in the Pure Lingsar complex. This study aims to (1) describe the history of Kemaliq Lingsar village, Lingsar District, west Lombok Regency. (2) Describe the valuea contained in Kemaliq Lingsar in Lingsar Village, Lingsar District, west Lombok Regency. (3) Describe the role of Kemaliq Lingsar for people's lives in Lingsar Vllage, Lingsar District, West Lombok Regency. This research method uses a qualitative approach. To get accurate data in this study using data collection techniques in the form of observation, interviews and documentation. The data analysis tecnique uses data reduction, data analysis, and data verification or drawing conclution. The result showed that Kemaliq Lingsar is a historic building located in the Pure Lingsar complex. Kemaliq was built in the 15th century AD by Datuk Milir. Kemaliq was later restored by Anak Agung Karang Asem Bali in 1714 becouse it was a complex with Pure Gaduh which was built as a place of worship for Hindus. Kemaliq Lingsar has social, religious and
\end{abstract}


cultural values for the life of the Lingsar community. In addition, Kemaliq Lingsar has a role in religion, social and economy in yhe life the Lingsar community.

Keywords: Values of History, Kemaliq, Society

\section{Pendahuluan}

Kemaliq Lingsar merupakan dianggap suci oleh masyarakat Sasak baik yang beragama Islam maupun yang beragama Hindu. ada dua alasan mendasar yang menyebabkan banguan ini menjadi banguan suci baik bagi umat Islam maupun Hindu yaitu (1) bangunan ini merupakan bukti peninggalan sejarah penyebaran agama islam di daerah Lingsar (2) bangunan ini berada di dalam komplek Pura Lingsar. Kemaliq lingsar dipugar oleh raja Karang Asem pada tahun 1714 M. Pemugaran bangunan ini disebabkan oleh karena berada dalam komplek tempat peribadatan bagi umat Hindu, selain itu raja memugar tempat ini supaya masyarakat suku Bali sebagai pemeluk agama Hindu dan masyarakat Sasak sebagai pemeluk agama Islam senantiasa Hidup berdampingan secara rukun.

Sebagai salah hasil kebudayaan bangunan Kemaliq Lingsar sampai saat ini selalu ramai dikunjungi terutama pada hari-hari libur baik oleh masyarakat Islam maupun Hindu. sebagai salah satu peninggalan sejarah bangunan ini mempunyai nilai-nilai sejarah tersendiri yang membedakannya dengan peninggalan-peninggalan sejarah yang terdapat di tempat atau daerah-daerah lainnya di Pulau Lombok. Keberadaan bangunan Kemaliq Lingsar yang berdekatan dengan tempat peribadatan umat Hindu menunjukkan bahwa perbedaan agama yang terdapat dalam masyarakat Sasak terutama di daerah Lingsar dapat hidup berdampingan secara rukun, damai, dan saling menghargai maupun bekerja sama. Hal ini memberikan gambaran bahwa agama hanyalah masalah keyakinan, dan keyakinan tidak menghalangi orang untuk bekerjasama.

Sebagai salah satu peninggalan sejarah kebudayaan Islam di daerah Lingsar dan tetap dilestarikannya bangunan Kemaliq Lingsar ini sudah tentu mempunyai nilai-nilai yang bermanfaat bagi masyarakat Sasak khususnya yang terdapat di daerah Lingsar. Kemaliq Lingsar sebagai salah satu hasil kebudayaan setidaknya mempunyai tiga wujud seperti yang dituturkan Taofik Abdullah, suatu kebudayaan sedikit-dikitnya mempunyai tiga wujud yaitu; 1) wujud gagasan, pkiran, konsep, dan sebagainya yang berbentuk abstrak; 2) dalam bentuk aktfitas yaitu berupa tingkah laku berpola, perlaku, upacara- 
upacara serta ritus-ritus yang wujudnya lebh konkrit; 3) dalam bentuk benda yang bisa merupakan hasil tingkah laku dan karya para pemangku kebudayaan yang bersangkutan oleh para ahli disebut dengan kebudayaan fisik (Abdullah, 1987: 5). Dalam konteks tersebut Kemaliq Lingsar dapat dipandang merupakan warisan secara turun temurun yang mempunyai sistem nilai, norma, pengetahuan, dan religi.

Theodorson mengemukakan bahwa nilai merupakan sesuatu yang abstrak, yang dijadikan pedoman serta prinsip-prinsip umum dalam bertindak dan bertingkah laku. Keterikatan orang atau kelompok terhadap nilai menurut Theodorson relatif sangat kuat dan bahkan bersifat emosional. Oleh sebab itu, nilai dapat dilihat sebagai tujuan kehidupan manusia itu sendiri (Pelly 1994: 44). Nilai budaya terdiri dari konsepsikonsepsi yang hidup dalam alam fikiran sebahagian besar warga masyarakat mengenai hal-hal yang mereka anggap amat mulia. Sistem nilai yang ada dalam suatu masyarakat dijadikan orientasi dan rujukan dalam bertindak (Koentjaraningrat, 1987: 85). Oleh karena itu, nilai budaya yang dimiliki seseorang mempengaruhinya dalam menentukan alternatif, cara-ara, alat-alat, dan tujuan-tujuan pembuatan yang tersedia.

Clyde Kluckhohn mendefinisikan nilai budaya sebagai konsepsi umum yang terorganisasi, yang mempengaruhi perilaku yang berhubungan dengan alam, kedudukan manusia dalam alam, hubungan orang dengan orang dan tentang hal-hal yang diingini dan tidak diingini yang mungkin bertalian dengan hubungan orang dengan lingkungan dan sesama manusia (Pelly 1994: 60). Sumaatmadja mengatakan bahwa pada perkembangan, pengembangan, penerapan budaya dalam kehidupan, berkembang pula nilai-nilai yang melekat di masyarakat yang mengatur keserasian, keselarasan, serta keseimbangan. Nilai tersebut dikonsepsikan sebagai nilai budaya (Marpaung 2000: 75).

Setiap individu dalam melaksanakan aktifitas sosialnya selalu berdasarkan serta berpedoman kepada nilai-nilai atau system nilai yang ada dan hidup dalam masyarakat itu sendiri. Artinya nilai-nilai itu sangat banyak mempengaruhi tindakan dan perilaku manusia, baik secara individual, kelompok atau masyarakat secara keseluruhan tentang baik buruk, benar salah, patut atau tidak patut. Suatu nilai apabila sudah membudaya didalam diri seseorang, maka nilai itu akan dijadikan sebagai pedoman atau petunjuk di dalam bertingkahlaku. Hal ini dapat dilihat dalam kehidupan sehari-hari, misalnya budaya gotong royong, budaya malas, dan lain-lain. Jadi, secara universal, nilai itu merupakan pendorong bagi seseorang dalam mencapai tujuan tertentu. Nilai sejarah adalah nilai yang 
terkandung dalam peristiwa pada masa lampau yang masih dapat dirasakan sampai saat ini. Begitupula pada Kemaliq Lingsar ada nilai-nilai sejarah yang terkandung di dalamnya yang menjadi keyakinan bagi umat Islam dan Hindu.

Kajian tentang Kemaliq Lingsar sudah pernah dilakukan oleh beberapa peneliti lain, diantaranya oleh I Made Karda (2015) tentang fenomena Kemaliq Lingsar analisis wetu telu (kajian perspektif budaya). Dalam penelitian ini menjelaskan bahwa fungsi Kemaliq Lingsar sebagai tempat persembahyangan dan sebagai tempat memohon keselamatan lahir dan batin. Sebagai tempat bertemunya atau berkumpulnya masyarakat dari berbagai etnis. Kemudian ada penelitian Ni Putu Sinta Dewi dkk. (2018) tentang eksistensi Pura Lingsar dalam dinamika toleransi antarumat beragama di Pura Lingsar. Dalam penelitian ini dijelaskan tentang makna tradisi perang Ketupat di Pura Lingsar dan korelasi sosio religious suku Sasak dengan suku Bali Beragama Hindu. Tentu kedua penelitian tersebut dapat memperkaya kajian ini dimana fokus utama kajian pada nilai dan peran Kemaliq Lingsar dalam kehidupan sosial dan budaya masyarakat Desa Lingsar Lombok Barat.

Penelitian ini tentu berbeda dengan penelitian sebelumnya dimana kajian ini lebih fokus pada nilai dan perannya dalam kehidupan masyarakat dalam konteks sosial dan budayanya. Tujuan dalam penelitian ini adalah untuk mengetahui dan memahami secara lebih mendalam tentang sejarah Kemaliq Lingsar, nilai-nilai yang terdapat pada Kemaliq Lingsar, dan peranan Kemaliq Lingsar bagi kehidupan masyarakat di Desa Lingsar Lombok Barat. Urgensi penelitian dapat menjadi salah satu khazanah budaya dalam memahami penghargaan atas perbedaan yang ada antara umat Islam dan Hindu di Lombok. Hal ini penting sebagai contoh bagi terbangunnya hubungan yang dialogis antara umat Islam dan Hindu dalam kehidupa sosial, budaya, dan agama yang harmoni.

\section{Metode Penelitian}

Penelitian ini menggunakan metode kualitatif dimana prosedur penelitian menghasilkan data deskriptif berupa kata-kata tertulis atau lisan dari orang-orang dan perilaku yang dapat diamati (Bambang, 2005; Arikunto, 2002). Metode kualitatif merupakan penelitian yang menggunakan latar ilmiah, dengan maksud menafsirkan fenomena yang terjadi dan dilakukan dengan jalan melibatkan berbagai metode yang ada (Moleong, 2005: 5). Fokus penelitian kualitatif ini berkaitan dengan sudut pandang individu-individu yang diteliti, uraian rinci tentang konteks, sensitivitas terhadap proses 
dan sebagainya dapat diruntut kepada akar-akar epistimologinya. Peneliti menjelaskan berbagai realitas yang terjadi di dalam bangunan Kemaliq Lingsar yang terdapat di Pura Lingsar Kecamatan Lingsar Kabupaten Lombok Barat.

Teknik pengumpulan data dalam penelitian ini menggunakan teknik obeservasi, wawancara, dan dokumentasi. Peneliti melakukan pengamatan dan mencatat tentang nilai-nilai Kemaliq Lingsar. Peneliti juga melakukan wawancara secara mendalam untuk mendapatkan hasil yang lebih akurat dan jelas. Kemudian dokumentasi dilakukan untuk mendapatkan arsip-arsip yang sesuai dengan Kemaliq Lingsar. Teknik analisis data menggunakan reduksi data, analisis data, dan verifikasi data atau penarikan kesimpulan (Sugiono, 2007). Hal ini dilakukan untuk mengungkap secara utuh fenomena Kemaliq Lingsar sebagai sebuah identitas budaya dalam suatu masyarakat.

\section{Pembahasan}

Kemaliq merupakan salah satu bangunan bersejarah yang berada di dalam komplek Pura Lingsar. Kemaliq dibangun pada abad ke-15 M oleh Datuk Milir. Datuk Milir adalah pengiring dari Syaik Abdul Malik dalam menyebarkan agama Islam di Lingsar. Adanya Kemaliq Lingsar juga menjadi bukti akan nama wilayah Lingsar dan timbulnya tradisi Pujawali yang diperingati sampai sekarang pada bulan ke tujuh menurut penanggalan Sasak. Daerah Lingsar dahulu kala adalah daerah tandus dan gersang, yang hanya ditumbuhi semak belukar dan dihuni oleh binatang-binatang melata dan liar. Setelah Syaik Abdul Malik dengan dua orang saudaranya yaitu KH. Abdul Rouf dan Hj. Raden Ayu Dewi Anjani datang ke daerah tersebut keadaan daerah lingsar yang tandus berubah menjadi makmur, hal ini karena disuatu malam yang hening, bulan dilangit sedang purnama karena malam itu tangal 15 menurut penanggalan Qamariyah, sasi kapitu (bulan ketujuh) menurut kalender sasak. Syaik Abdul Malik yang sedang berkhalwat semalam suntuk, beliau bangun dari tempat khalwatnya besok harinya menjelang sholat ashar.

Beliau lalu berjalan dengan pelan dengan memegang tongkat menuju kesebuah kaki bukit dan beliau berhenti disebuah pohon waru yang hanya tumbuh sebatang kara. Dibawah pohon waru tersebut beliau berdoa lalu beliau menancapkan tongkat yang ada ditangannya kedalam tanah. Tongkat tersebut lalu dicabutnya dan dari tanah itu keluar air yang sangat deras, suara airnya terdengar sampai jauh dan bersamaan dengan itu bunga- 
bunga pohon waru jatuh berguguran. Peristiwa tersebut kemudian disebut dengan Rarak Kembang Waru. Dari peritiwa keluarnya air itu terciptalah nama Lingsar. "Ling" dalam bahasa sasak berarti suara dan "sar" artinya suara atau bunyi air. Peristiwa itu kemudian hingga sekarang diperingati setiap tahun saat bulan purnama, sasi kapitu menurut wariga sasak (bulan ketujuh menurut kalender sasak). Perlu diketahui bahwa pohon waru yang dijadikan tempat oleh Syaikh Abdul Malik untuk berkhalwat berada di Kemaliq sekarang (Taufik, Wawancara Pribadi, 10 Juli 2020).

\section{Perang Topat Sebagai Upacara Penghormatan Terhadap Syaikh Abdul Malik}

Untuk menyambut kehadiran air yang ada di Lingsar yang dulunya tandus, kemudian menjadi subur dan makmur, diadakan upacara Rarak Kembang Waru yang terdiri dari upacara khaul KH. Abdul Malik dan upacara perang Topat. Perang Topat mulai diadakan sejak keluarnya mata air Lingsar, sebagai sebuah ekspresi yang menunjukkan rasa suka cita atas peristiwa keluarnya air mata air. Perang Topat ini diadakan oleh Syaikh KH. Malik untuk mendamaikan dan merukunkan kehidupan masyarakat di Lombok. Dahulu, sebelum Syaikh KH. Abdul Malik datang ketanah Lombok, orang-orang Sasak yang mendiami tanak Lombok terdiri dari kelompokkelompok yang dipimpin oleh datu atau raja kecil.

Pada waktu itu, untuk menjadi seorang datu (raja) dia harus memiliki oleh kanuragan (kesaktian) agar menjadi pemenang dalam pemiliha datu (raja). Jika dia sebagai pemenang, dia akan menjadi datu, sebelum dinobatkan menjadi datu, dia akan diarak keliling pada komunitasnya yang disebut praja. Setelah itu, dia berhak disebut raja. Gelar datu ini sampai sekarang masih banyak dipakai di tanah Lombok. Kelompokkelompok ini satu dengan yang lainnya sering terjadi peperangan secara fisik, maka oleh Syaikh KH. Abdul Malik, kelompok-kelompok ini disatukan dengan peperangan diantara mereka dialihkan menjadi perang Topat (perang ketupat), perang yang membawa kedamaian dan kerukunan. Sejak adanya perang topat diadakan supaya manusia bersyukur kepada Tuhan dan supaya mereka hidup rukun, damai, dan saling mengasihi.

Perang Topat sebagai simbol melempar syaitan, supaya selamat dari godaan syaitan yang selalu menjerumuskan manusia ke lembah kehancuran. Oleh karena itu, setelah selesai Perang Topat, para peserta tidak ada dendam, walaupun ada di antara mereka yang wajahnya luka atau badannya lebab, terkena lemparan topat. Beberapa waktu kemudian 
setelah selesai peristiwa Rarak Kembang Waru di atas, pengiring Syaikh KH. Abdul Malik, yaitu KH. Abdul Rouf memohon izin kepada beliau untuk melanjutkan syiar Islam ke tanah Bali dan setelah mendapat restu, beliau berangkat ke Bali bagian timur (daerah Pegayoman) dan pengabih (pengawal) Syaikh KH. Abdul Malik Hj. R Ayu Dewi Anjani memohon izin pula untuk melakukan syiar Islam pada golongan jin ke Gunung Rinjani, sehingga semua jin yang ada disekitar Gunung Rinjani memeluk agama Islam. Islam di Lingsar disebarkan oleh tiga ulama yang berasal dari Jawa yaitu Syaikh KH. Abdul Malik, Syaikh Abdul Rauf dan $\mathrm{Hj}$. Dewi Anjani. Kemaliq Juga menjadi bukti akan bukti penyebaran agama Islam di Lingsar.

\section{Keberadaan Kemaliq dalam Komplek Pura Lingsar}

Bentuk Kemaliq yang ada pada waktu dulu tidak sama dengan yang ada pada saat sekarang ini. Yang kita lihat pada saat sekarang ini merupakan bangunan Kemaliq yang sudah dipugar oleh Anak Agung Karang Asem Bali pada tahun 1714. Anak Agung memugar tempat itu karena berada dalam satu komplek dengan Pura Gaduh yang dibangun sebagai tempat beribadahnya umat Hindu. Kedatangan Anak Agung ke wilayah Lingsar jauh setelah adanya bangunan Kemaliq Lingsar. Supaya tidak terjadi permusuhan kelak dikemudian hari maka anak agung memerintahkan agar tidak merusak bangunan yang tela hada akan tetapi disuruh untuk dipugar (I Ketut Lingga Bagianta, Wawancara pribadi, 12 Juli 2020).

Kemaliq Lingsar terutama dijadikan juga sebagai tempat perayaan Perang Topat. Perang Perang Topat sesungguhnya adalah sebagai napak tilas akan perjalalan yang dilakukan oleh masyarakat untuk mengenang perjuangan Syaikh KH. Abdul Malik. Sebagai sebuah kenyataan yang tidak dapat dihilangkan bahwa terdapat nilai-nilai tersendiri yang melekat dalam sebuah peninggalan sejarah. Nilai tesebut menjadi tolak ukur akan keberadaan situs sejarah. Situs sejarah yang mempunyai nilai yang bermanfaat bagi masyarakat menunjukkan akan kualitas dan keistimewaan dari peninggalan tersebut. Peninggalan yang baik akan banyak menyimpan sejarah dan manfaat yang banyak bagi generasi penerus masyarakatnya. Kemaliq Lingsar menyimpan sejarah penyebaran dan kebesaran agama Islam di Desa Lingsar. Sebagai sebuah peninggalan terdapat beberapa nilai yang terkandung di dalam bangunan Kemaliq Lingsar. 
Kemaliq Lingsar merupakan salah satu bangunan bersejarah yang terdapat di Desa Lingsar Kecamatan Lingsar. Sebagai bangunan bersejarah. Kemalik Lingsar mempunyai arti tersendiri bagi masyarakat Lingsar, karena dari tempat inilah pertama kali air keluar yang menyebabkan daerah Lingsar menjadi daerah yang subur seperti sekarang ini. Karena nilai sejarah ini keberadaan Kemaliq Lingsar menjadi tempat yang dikeramatkan oleh masyarakat Sasak Islam dan umat Hindu (Syafiudin, Wawancara Pribadi, 15 Juli 2020).

Nilai-nilai yang terdapat pada Kemaliq Lingsar yang berada pada komplek Pura Lingsar yakni:

\section{a. Nilai Sosial}

Nilai sosial adalah nilai yang menempatkan kasih saying antara manusia sebagai tempat tertinggi (Mulyana dan Jalaluddin, 2006: 33). Nilai sosial ini berhubungan dengan masyarakat. Keberadaan Kemaliq Lingsar di Pura Lingsar mempunyai nila sosial yang sangat besar terutama bagi dua suku yang terdapat di Desa Lingsar yaitu suku Sasak yang merupakan penduduk asli dan orang-orang Bali. Suku Sasak merupakan penduduk asli Desa Lingsar, orang-orang Sasak telah mendiami tempat ini sejak dahulu kala yaitu sejak perpindahan penduduk atau migrasi yang dilakukan oleh orang-orang yang berasal dari Yunan pada tahun 2000-1500 SM yang dikenal dengan Proto Melayu, Proto Melayu inilah yang melahirkan suku Sasak sedangkan pendapat lain mengatakan bahwa nenek moyang orang Sasak berasak dari Jawa, hal ini terutama ketika terjadi penguasaan Lombok atas kerajaan Majapahit, pada saat Mahapatih Gajah Mada melaksanakan sumpah lapanya. Tentang asal-usul masyarakat Sasak ini terdapat dalam Babat Lombok.

Suku Bali merupakan bangsa pendatang, mereka datang untuk pertama kalinya di bumi Selaparang ini untuk mencari daerah yang subur sebagai tempat pertanian. Imigran pertama orang-orang Bali ini kemudian mendirikan kerajaan Pagutan dan Pegasangan. Kedatangan kedua orang-orang Bali ke Lombok adalah dalam rangka menyerbu kerajaan Pejanggik dan Selaparang atas permintaan Arya Banjar Getas. Kedatangan orang-orang Bali ke Lingsar adalah dalam rangka perjalanan Anglurah Karang Asem yang akan berangakat ke Selaparang, akan tetapi mereka mengambil jalan lewat Lingsar. Pada akhirnya atas perintah dari sang raja dibangunlah Pura Lingsar dan dipugar juga Kemaliq yang terdapat dalam wilayah itu. Itulah awal keberadaan orang-orang Bali di wilayah Lingsar. Dengan menetapnya orang-orang Bali diwilayah ini terdapat dua suku yang 
mendiami wilayah Lingsar sampai saat ini yaitu suku Sasak dan suku Bali, walaupun mereka berbeda agama akan tetapi mereka hidup dengan rukun dan damai.

Keberadaan Kemaliq Lingsar menjadikan mereka hidup rukun dan damai. Kerukunan diantara mereka dapat terlihat oleh bangunan Kemaliq Lingsar yang notabene merupakan tempat yang dianggap suci oleh umat Islam Sasak akan tetapi berada di dalam komplek Pura Lingsar. Keberadaan Kemaliq Lingsar di dalam komplek Pura Lingsar bahkan sangat berdekatan dan dihalangi oleh tembok menunjukkan hubungan yang terbangun diantara suku Sasak dengan Bali. Selain itu, kerukunan diantara mereka juga tercermin dari pelaksanaan upacara Pujawali. Yang dilakukan secara bersama-sama antara suku Sasak yang beragama islam dengan orang Bali yang beragama Hindu.

b. Nilai Budaya

Sebagai situs sejarah dan budaya, Kemaliq Lingsar mempunyai nila-nilai budaya yang manfaatnya dapat dirasakan oleh mereka yang berada di wilayah Lingsar. Karena menyimpan nilai budaya yang sangat bermanfaat, maka sudah semestinya banguan Kemaliq Lingsar untuk dilestarikan. Adanya Pura Lingsar dan Kemaliq Lingsar desa Lingsar menjadi dikenal dimana-mana. Banyak pengunjung yang datang untuk melihat peninggaan sejarah yang terdapat pada Kemaliq Lingsar.

c. Nilai Agama

Keberadaan Kemaliq Lingsar yang dianggap suci oleh dua etnis Sasak dan Bali dapat meningkatkan hubungan antara mereka. Selain itu, keberadaan Kemaliq Lingsar menyimpan-nilai-nilai agama bagi para pemeluknya. Bagi umat Islam Kemaliq Lingsar dapat meningkatkan keimanan dan ketakwaan kepada Tuhan Yang Maha Esa. hal ini disebabkan oleh karena Kemaliq Lingsar mempunyai sejarah yang berkaitan dengan penyebaran agama Islam di wilayah Lingsar. Bagi masyarakat yang mengetahui akan sejarah Kemaliq Lingsar dapat dijadikan sebagai sarana untuk meningkatkan keimanan kepada Allah SWT.

Sedangkan bagi umat Hindu Kemaliq juga dijadikan sebagai tempat pemujaan terhadap Sang Hyang Widi Wase. Di dalam Kemaliq Lingsar terdapat berbagai bacam patung-patung yang dijadikan sarana pemujaan umat Hindu kepada Tuhan mereka. Bagi umat Hindu selain Pura Lingsar Kemaliq juga dijadikan sebagai tempat sembahyang. Bangunan yang terdapat pada Kemaliq Lingsar memiliki makna tersendiri yakni: 
1. Di dalam Kemaliq Lingsar terdapat Tangga penghubung antara Kemaliq dan Pura Gaduh berjumlah 17 buah, maknanya; Al-Qur'an diturunkan pada tanggal 17 Ramadhan, tiap-tiap orang muslim sembahyang 17 rakaat satu hari satu malam, kalau digabungkan kedua tangga tadi karena banyaknya dua maka akan menjadi 2 x $17=34$ $=7$ ini menunjukkan keyakinan adanya tujuh pertalian buli dan langit dan tujuh jumlah hari, juga dikaitkan dengan hari lahirnya Negara Republik Indonesia berarti 17 Agustus, hari proklamasi kemerdekaan Indonesia, dan di muka Kemaliq terdapat tibu suyun berbintang delapan dan dus sepekat, maknanya adalaha Air di Kemaliq ini akan memberikan kehidupan bagi semua penjuru tanah Lombok, bahkan penjuru dunia. Dan delapan sering disebut windu, sewindu sering dipakai untuk mengukur tinggi rendahnya atau besar kecilnya kesetiaan orang kepada Negara serta pada bagian selatan atau seberang tembok dalam Kemaliq terdapat pancoran, yang dalam istilah halusnya disebut pesiraman. Pesiraman ini dibagi dua sebelah timur dan barat. Sebalah timur ada empat buah dan sebelah barat ada lima buah.

2. Di Luar Kemaliq Lingsar terdapat banyak bangunan-banguna. Bangunan ini mempunyai makna dan arti tersendiri yakni pertama Pancoran Sembilan, pancor ini disebut pancor siwa' terdapat di dua tempat dan untuk orang lak-laki dan wanita. Masing-masing pancor tetap berjumlah Sembilan dan terdapat pancor luji yang jumlah pancornya dua buah. Kedua Balai jajar, rumah sejajar. Balai ini letaknya sejajar yang berada disebelah utara tempat ini digunakan untuk tempat kesenian bagi umat Hindu, dan terdapat juga disebelah selatan yang diperuntukan untuk tempat kesenian bagi orang-orang sasak. Kedua balai ini bertiang delapan, bentuknya pun sama dan sebangun makanya pemerintah (raja Karang Asem) menghendaki supaya antara suku bali dan sasak duduk sama rendah berdiri sama tinggi. Tiap-tap warga kerajaan mempunyai hak, kewajiban, dan kedudukan sosial yang sama dan harus selalu sejajar, berat sama dipikul ringan sama dijinjing. Derap langkah di dalam memikul tanggung jawab pembangunan harus dipikul bersama terpadu dan terarah. Ketiga Balai Bundar berbentuk bundar dengan makna Balai Bundar dengan tiang delapan sebagai simbol pemersatu supaya masyarakat bersatu jangan pecah belah bahkan kalau perlu seluruh penjuru mata angin dimana manusia harus bersatu atas dasar saling harga menghargai, hormat menghormati. Keempat Bencingah berasal dari kata bencangah yang berarti 
tempat menghadap rakyat atau tempat raja memberi petuah, nasehat atau saran-saran kepada masyarakat.

Kemaliq Lingsar memiliki peran yang sangat penting dalam bidang agama terutama bagi umat Hindu. Ini terlihat pada komplek Kemaliq Lingsar terdapat patung-patung yang dijadikan sebagai sarana pemujaan bagi umat Hindu. bagi umat Hindu pemujaan tidak hanya dilakukan di Pura Gaduh akan tetapi mereka juga dapat melakukan ibadah di dalam Kemaliq Lingsar. Sedangkan dalam bidang sosial bentuk kehidupan sosial yang dibangun oleh suku Sasak dan Bali di Desa Lingsar merupakan salah satu contoh kerukuna antar umat beragama. Kerukunan yang tercipta tentu tidak bisa dilepaskan dari adanya bangunan-bangunan bersejarah yang terdapat di desa ini. Apalagi dalam satu tempat terdapat dua buah bangungan yang satu milik orang Hindu sedangkan yang lainya melik suku Sasak Islam. Sampai saat ini Kemaliq Lingsar mempunyai peran yang sangat besar bagi masyarakat Desa Lingsar baik itu yang beragama Hindu maupun yang beragama Islam. Menurut kalangan etnis Bali, Kemaliq disebut juga dengan Pura Kemaliq.

Pura dan Kemaliq berfungsi sebagai tempat pemujaan Sang Hyang Parama Gangga, suatu manifestasi Tuhan Yang Maha Esa dalam fungsinya sebagai penguasa air dan juga sebagai tempat memuja Batara Gede Lingsar. Kemaliq ini diyakini sebagai tempat suci dan keramat dan juga sebagai tempat orang-orang Sasak yang mengikuti ajaran dari Pangeran Sinopati melakukan persembahyangan bersama-sama umat Hindu. ada pula istilah bhuwah loka yang menurut kalangan orang Bali di Lingsar sebagai alam darat untuk menyebut Kemaliq tersebut.

Ada banyak peran yang terkandung dalam ritual Pujawali bagi masyarakat Lingsar secara khusus dan Lombok umumnya yakni: Pujawali menjadi jembatan bagi masyarakat Sasak Islam dengan Hindu untuk saling berintreaksi, menjalin hubungan yang erat dengan banyak perbedaan namun dapat disatukan dengan ritual Pujawali. Bahkan untuk menghilangkan perbedaan diantara mereka dan supaya tidak menimbulkan konflik antara pemeluk agama Islam dan agama Hindu ketika melakukan napak tilas, mereka menggunakan kerbau. Pemeluk agama Islam tidak menggunakan sapi karena sapi merupakan binatang suci bagi agama Hindu, kalau pemeluk agama Islam memaksanakan keinginannya untuk menggunakan sapi, maka akan timbul ketegangan antara agama islam dan hindu padahal ritual pujawali merupakan ritual bersama yang dilaksanakan oleh pemeluk agama Hindu dan agama Islam. Sedangkan agama Hindu tidak menggunakan 
babi sebagai sarana untuk melakukan napak tilas, karena menghormati pemeluk agama Islam yang mengharamkan daging babi.

Masyarakat bisa menjalin kearifan, kerukunan antar umat beragama. Dewasa ini sering terjadi konflik antar agama yang berbeda padahal konflik yang terjadi disebabkan oleh hal-hal yang sifatnya sepele, akan tetapi konflik tersebut menjadi besar ketika mereka yang terlibat mengatas namakan agama. Di Desa Lingsar terdapat berbagai macam agama yang berbeda, akan tetapi yang menojol hanya agama Islam dan agama Hindu. adanya ritual pujawali yang diikuti oleh pemeluk agama yang berbeda menunjukkan bahwa telah tercipta kerukunan antar agama yang berbeda, dan memang telah menjadi sebuah tradisi sejak dahulu kala bahwa yang terlibat dalam setiap rangkaian kegiatan adalah pemeluk agama Islam dan agama Hindu. kerukunan yang tercipta tidak hanya pada saat perayaan Pujawali akan tetapi berlanjut sampai setelah ritual ini selesai. Salah satu bentuk kerukunan yang tercipa selain itu bahwa didalam komplek Pura Lingsas terdapat bangunan Kemalik Lingsar yang sejatinya merupakan maqam Syaik KH. Abdul Malik.

Dalam bidang budaya salah satu hal yang patut dibanggakan oleh masyarakat yang ada Desa Lingsar ini adalah adanya bangunan Kemaliq Lingsar.Selain sebagai tempat ibadah bagi umat Hindu. Kemaliq termasuk salah satu peninggalan kebudayaan Islam di wilayah Lingsar. Kemaliq telah banyak memberikan kontribusi bagi masyakat Lingsar khususnya dan Lombok pada umumnya. Dengan adanya Kemaliq Lingsar tak luput pula peran ekonomi karena dengan adanya Kemaliq tersebut bisa meningkatkan perekonomian masyarakat setempat. Ini terlihat setelah banyaknya pengunjung masyarakat setempat membuka warung dan kios-kios dan bahkan banyak masyarakat yang menjajalkan jualannya di Pure.

\section{Kesimpulan}

Keberadaan Kemaliq Lingsar tidak bisa dipisahkan dari peran seorang ulama atau penyebar agama islam yang berasal dari Jawa, yang konon menancapkan tongkatnya dengan haparan supaya daerah yang tandus (sekarang bernama Lingsar) dapat subur. Adanya banguan Kemaliq Lingsar menyimpan nilai-nilai sejarah bagi kita semua, selain 
nilai-nilai sejarah Kemaliq Lingsar juga mempunyai nilai-nilai yang lain seperti nilai sosial, agama, dan nilai budaya. Peran Kemaliq Lingsar bagi kehidupan masyarakat dapat terlihat dari fungsi Kemaliq bagi masyarakat Islam Sasak dan Hindu Bali. Kedua etnis tersebut mengambil manfaat akan adanya Kemaliq Lingsar misalnya didalam Kemaliq terdapat patung-patung yang dijadikan sebagai tempat pemujaan bagi umat Hindu sedangkan di dalam Kemaliq terdapat juga pancuran yang mempunyai penapsiran bagi umat Islam.

\section{Daftar Rujukan}

Abdullah, Taufik. (Editor), (1987), Sejarah dan Masyarakat, Jakarta: Pustaka Pirdaus.

Arikunto, Suharsimi. (2002), Prosedur Penelitian Suatu Pendekatan Praktis, Jakarta Rineka Cipta, IKIP.

Bambang, Prasetyo, (2005), Metode Penelitian Kuantitatif Teori dan Aflikasi, Jakarta: Raja Grafindo.

Ibrahim, Abdul Syakur. (2006), Metode Penelitian Kualitataif, Malang:

Karda, I Made. (2015). Fenomena Kemaliq Lingsar Analisis Wetu Telu (Kajian) Perspektif Budaya. Media Bina Ilmiah, 9 (2). 23-30

Koentjaraningrat, (1987), Kebudayaan, Mentalitas, dan Pembangunan, Jakarta: Djambatan.

Moleong, Lexy J, (2004). Metodologi Penelitian Kualitatif, Bandung: PT. Remaja Rosda Karya.

Mulyana dan Rakhmat, Jalaluddin (2006), Komunikasi Antar Budaya: Panduan berkomunikasi dengan orang-orang berbeda budaya.. Bandung: Remaja Rosdakarya.

Pelly, 1994, Pengantar Sosiologi, Jakarta: Erlangga.

Dewi, Ni Putu Sinta dan Nerawati, N. G. A., \& Widiana, I. G. P. G. (2018). Eksistensi Pura Lingsar dalam Dinamika Toleransi Antar Umat Beragama di Nusa Tenggara Barat (Perspektif Filsafat Hindu). Jurnal Penelitian Agama Hindu. 2 (1). 442-430.

Sugiono, (2007). Metode Penelitian Kualitataif, Kuantitatif dan R\&B, Bandung: Alfabeta.

Wawancara dengan Bapak Taufik, 10 Juli 2020.

Wawancara dengan Syafiudin, 15 Juli 2020.

Wawancara I Ketut Lingga Bagianta, 12 Juli 2020. 